Рекомендована д. біол. наук, проф. Л. С. Фірою

УДК 615.322-092.8]-092.4

DOI 10.11603/2312-0967.2016.4.7129

\title{
ОГЛЯД НАУКОВИХ ДОСЛІДЖЕНЬ 3 МЕТОЮ ОДЕРЖАННЯ НОВИХ ФІТОПРЕПАРАТІВ НА ОСНОВІ ГЕРАНІ СИБІРСЬКОЇ
}

\author{
() О. І. Гордієнко ${ }^{1}$, І. Л. Бензель ${ }^{2}$, Т. А. Грошовий ${ }^{1}$
}

\author{
ДВНЗ «Тернопільський державний медичний університет імені І. Я. Горбачевського \\ МОЗ України» ${ }^{1}$ \\ Львівський національний медичний університет імені Данила Галицького
}

Резюме: в огляді літератури узагальнено дані про ботанічну характеристику, розповсюдження, хімічний склад і застосування герані сибірської.

Ключові слова: герань сибірська, Geranium sibiricum L., ботанічна характеристика, хімічний склад, застосування.

Вступ. Наукова і практична медицина поряд із використанням новітніх фрармацевтичних препаратів дедалі частіше звертається до цілющих властивостей лікарських рослин, знаходячи несподівані й бажані відповіді у лікуванні та профрілактиці різних захворювань. До таких рослин можна віднести рід Герань (Geranium L.), який нараховує понад 300 видів. На території України широко розповсюдженні більше 20 видів гераней $[1,2]$.

Мета роботи - систематизація результатів ботанічного, фрітохімічного і фрармакологічного вивчення рослини герані сибірської.

Ботанічна характеристика і поширення.

Герань сибірська (Geranium sibiricum L.) - дворічна або багаторічна трав'яниста рослина, заввишки 20-60 см. Стебло висхідне або прямостояче, здебільшого слабке, практично від основи і вище багаторазово розгалужене, вкрите притиснутими простими, незалозистими волосками. Листки у герані невеликі, діаметром 1,5-5 см. Пластинки листків розсічені на 3-5 ромбічних часток, які у верхній половині неправильно гостро або тупувато-перистонадрізані. Прикореневі листки 5-7-лопатеві, рано відмирають, стеблові супротивні на довгих, до 8 см завдовжки, черешках. Прилистки до 8 мм завдовжки, ланцетні, довгозагостренні, шкірясті. Квітконоси рослини одноквіткові, дуже рідко несуть по дві квітки. Вони виходять поодинці із пазух стеблових листків. Квітконіжки тонкі, після цвітіння відігнуті вниз, а на верхівці висхідні. Чашолистики 5-6 мм завдовжки, по жилах негусто вкриті волосками нерівної довжини, між жилками зазвичай шорсткі. Пелюстки 4-7 мм завдовжки та 2-3 мм завширшки, оберненояйцеподібні, цілісні або трохи виїмчасті, по краях війчасті, при основі 3 нечисленними короткими і тонкими волосками або голі, білі або блідо-рожеві. Нитки тичинок довгастояйцеподібно розширені до основи, по краях з дуже короткими і нерівними за довжиною волосками, дуже рідко голі. Плоди овальні завдовжки до 2 см, покриті довгими жорсткими волосками; насіння найтонше, лінійно-точкове. Цвіте герань сибірська в червні-липні, а плодоносить у липні-вересні [1-4].

Герань сибірська поширена в європейській частині Росії (Прибалтійський, Ладозьке-Ільменський, Верхньоволзький, Волзько-Донський, Заволзький райони), в Україні (Середньодніпровський район), у Західній (всі райони) та Східній (всі райони, крім Єнісейського) частині Сибіру, на Далекому Сході (всі райони, за винятком, Охотського і Камчатського), в Середній Азії. Цей вид широко розповсюджений на Кавказі, в Західному Китаї, Монголії, Японії, Кореї, Маньчжурії та Південній Америці $[1,5]$. В Україні найбільшою сировинною базою характеризуються Закарпаття, Західне Полісся, Правобережне Полісся (Рівненська, Житомирська та Київська області), Західноукраїнські ліси, Західний Лісостеп (Тернопільська і Хмельницька області), Правобережний Лісостеп (Вінницька і Черкаська області) $[2,6]$.

Герань росте на берегах річок, озер, пустирях, узліссях; зустрічається на полях, в парках, а також на околицях соснових борів, по вигонах. До ценокомплексу герані сибірської входять підболочені і відкриті луки, чагарники і відкриті кам'янисті схили. Як бур'ян зустрічається вздовж доріг, на залізничних насипах, покладах і ріллі [5, 7].

\section{Рослинна сировина та її заготівля.}

Як рослинну сировини використовують траву і кореневища $з$ коренями герані сибірської. Траву збирають в період бутонізації, цвітіння, іноді плодоношення. Ії̈ зрізають ножем або спеціальним секатором біля основи або на рівні нижніх листків. Сушать на відкритому повітрі в тіні або в теплих провітрюваних приміщеннях, розкладаючи шаром 3-5 см на папері або тканині. Кореневища 3 коренями збирають

ISSN 2312-0967. Pharmaceutical review. 2016. № 4 


\section{Reviews}

восени після обльоту насіння, коли починає в'янути надземна частина. Збір підземних органів рослини проводять викопуючи її із землі лопатами, мотиками, вилами - залежно від особливостей ґрунту і умов зростання. Викопану підземну частину обережно обтрушують від землі і швидко промивають. Вимиту сировину тут же розкладають на підстилці, щоб вона підсохла, розкладаючи шаром 5-7 см, потім очищають від тонких корінців. Термін придатності сировини трави - 2 роки, а кореневищ 3 коренями - 3 роки [3].

Стандартизація за даними Т. А. Позднякової

Для трави герані сибірської розроблені числові показники якості сировини, які включають: вміст суми фрлавоноїдів у перерахунку на цинарозид не менше 2,5 \%; екстрактивні речовини, вилучені спиртом етиловим $50 \%$ не менше 35 \%; вміст загальної золи не більше $14 \%$; вміст золи, не розчинної в $10 \%$ кислоті хлоридній, не більше $1 \%$; вологість не більше $13 \%$ [8].

Фітохімічний склад трави і кореневищ з коренями герані сибірської.

Літературні дані і дослідження науковців свідчать, що хімічний склад герані сибірської представлений широким спектром біологічно активних речовин (БАР) переважно фенольної природи, якісний та кількісний склад яких значно залежить від екологокліматичних умов зростання та френофрази заготівлі сировини.

Так, у підземній частині рослини вміст дубильних речовин змінюється від 6,05 до 30,0 \%, а у надземній - від 1,1 до 25,3 \%. Кількість фрлавоноїдів у траві вказаної рослини становить 0,47-0,9%. В підземній частині герані сибірської знайдений танін у кількості 4,7 \%, та гераніїн (0,87 \%). Листя містить 20,3 \% таніну, в стеблах його кількість є значно нижчою (3,8 \%). Крім того, із рослини виділені дві сполуки похідних пірогалол таніну. При тривалому зберіганні вказаної сировини вміст БАР значно зменшується [9-11].

Кількість галової та елагової кислот відрізняється залежно від онтогенезу та виду сировини герані сибірської. Рослина має більший вміст вільної елагової кислоти на початку вегетації у траві та зв'язаної елагової кислоти у кореневищах. У фразу масового цвітіння спостерігається вищий вміст вільної елагової кислоти у траві герані порівняно з кореневищами, а зв'язаної елагової кислоти у кореневищах виявилось більше, ніж у траві [12].

Дослідження кількісного вмісту поліфенольних сполук показало, що в траві герані сибірської в перерахунку на суху сировину їх міститься 10,72 $\pm 0,23 \%$

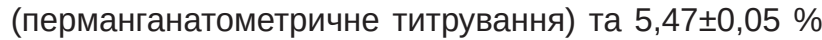
(метод спектрофотометрії), а в коренях відповідно $3,16 \pm 0,11$ та 2,42 $\pm 0,04 \%[13,14]$.

За допомогою ВЕРХ у траві герані сибірської досліджено, що вміст галової кислоти до гідролізу становить 0,18 \%, елагової кислоти - 0,35 \%, кверцетину - 0,0007 \% і рутину - 0,28 \%. Після гідролізу кількість досліджуваних речовин збільшується через існуван- ня у траві герані комплексів корилагіну і гераніїну. Вміст галової кислоти при цьому становить - 0,50\%, елагової кислоти - 0,75 \%, кверцетину - 0,02 \%. Після гідролізу рутин не був виявлений у випробуваних зразках. Вміст катехіну у траві герані сибірської становить 0,071\% [15].

Використовуючи методи хроматограсрічного та спектрального аналізу, у траві герані сибірської ідентифіковано ряд сполук фенольної природи: галову, бурштинову, ферулову, коричну та неохлорогенову кислоти, кверцетин, дигідрокверцетин, лютеолін, лютеолін-7-глюкозид, катехін, епікатехінгалат, епікатехін, дикумарин, кумарин і 7-О-метоксикумарин. Встановлено, що з речовин кумаринової природи найбільше міститься дикумарину (3,83 \%), з фрлавоноїдних сполук - лютеоліну (18,17 \%) і його 7-глюкозид $(9,55 \%), ~ з$ френолокислот переважає галова кислота (12,10\%), а з похідних дубильних речовин - епікатехін (23,73 \%) у перерахунку на загальний вміст френольних сполук $[11,14,16]$.

Разом 3 основними діючими речовинами 3 рослини герані сибірської виділено вітамін С, каротиноїди, та нову сполуку - етил бревіфолінкарбоксилат, який певною мірою проявляє антибактеріальну активність $[11,17]$.

За допомогою спектрофротометрії визначено спирторозчинні моносахариди в траві досліджуваної рослини, вміст яких становить 3,32士0,05 \% у перерахунку на глюкозу, а також водорозчинні полісахариди

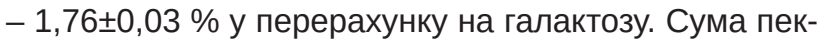
тинових речовин у траві герані сибірської дорівнює 8,54ะ0,10 \% у перерахунку на галактуронову кислоту. щодо кількісного вмісту суми геміцелюлоз, то їх кіль-

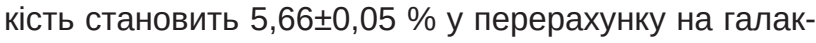
тозу [18].

Після виділення поліфенольних сполук і водорозчинного полісахаридного комплексу $(7,01 \%)$ із повітряно-сухої трави вихід пектинових речовин становить 11,07 \%. За допомогою титрометричного методу встановлено, що вміст вільних карбоксильних груп становить 5,46 \%, метоксильованих карбоксильних груп - 0,56 \%, загальна кількість карбоксильних груп - 6,02 \%, метоксильних груп - 0,38 \%, ступінь метоксилювання - 9,30\%. Пектинові речовини трави герані сибірської характеризуються невисоким $(\lambda<$ 50 \%) ступенем етерифрікації, що дає можливість використання їх у медичній практиці як детоксикантів і у фрармацевтичній практиці при виробництві лікарських препаратів як гелеутворюючі агенти [19].

Переважаючими моноцукрами у водорозчинному полісахаридному комплексі виступають галактоза $(14,1 \%)$ і арабіноза (11,6 \%), серед пектинових речовин головна - галактуронова кислота (87,5 \%), основою геміцелюлоз А і Б є ксилоза (8,1 і 8,7 \% відповідно) [20].

Амінокислотний склад трави герані сибірської вивчений достатньо добре для його обґрунтування. Су-

ISSN 2312-0967. Фармацевтичний часопис. 2016. № 4 
марний вміст вільних амінокислот становить близько 7,7 мг/г, причому їх накопичення зростає при штучному культивуванні рослин, але практично не змінюється в умовах стресу. Основний внесок в накопиченні вільних амінокислот вносять аспарагін і пролін. При цьому якісний склад амінокислот в культивованих рослинах і тих, які ростуть в природних умовах ідентичний [21].

При дослідженні трави герані сибірської зібраної в різних місцях зростання і в різні фрази вегетації було встановлено наявність 29 вільних амінокислот, 3 яких 8 незамінні. Основними 3 них $є$ аргінін, треонін, серин, валін, тирозин, ізолейцин та фенілаланін $[22,23]$.

Використовуючи метод перегонки 3 водяною парою, визначено вміст ефрірної олії в траві герані сибірської, який становить 0,06 \%. Вона являє собою легкорухливу рідину жовтуватого кольору з приємним специфічним запахом [24].

Методами хроматографії та спектрометрії у траві герані сибірської ідентифіковано більш ніж 60 летких сполук, а у кореневищах - 42, з яких $11 €$ спільними для обох зразків досліджуваної сировини. Сумарний вміст летких сполук вищий у кореневищах рослини і становить - 289 мг/кг, у траві він досягає 161,1 мг/кг [25].

3-поміж індивідуальних компонентів у траві герані сибірської домінує сквален, гексафрарнезилацетон, каріофріленоксид, гераніол, гексакозан, фрітол і пальмітинова кислота. У кореневищах з коренями найвищий вміст серед виявлених летких сполук припадає на жирні кислоти - пальмітинову, нонанову та пентадеканову, а також на френілацетальдегід і геранілацетон. Також сировина містить терпени та терпеноїди - $\alpha$-терпінеол, цитронелол, пара-цимен-7-ол, карвон, $\beta$-каріофрілен, гермакрен тощо [24, 25].

За допомогою спектрофотометрії в траві герані сибірської визначено кількісний вміст каротиноїдів, що складає 2,59 \pm 0,12мг /\% [26].

Використовуючи біохімічну реакцію гемаглютинації у кореневищі герані сибірської встановлено вміст лектинів, титр яких дорівнює $2^{7}$. Виявлено, що цей показник збільшується протягом сезонного розвитку (від початку вегетації до цвітіння рослин) [27].

Біологічна активність сполук герані сибірської та їх застосування.

У народній медицині герань сибірська використовується для лікування запалення кишечнику, дерматиту та раку. Настій і відвар трави та кореневищ із коренями у співвідношенні 1:20 застосовують як в'яжучий, гемостатичний засіб при проносах та різних кровотечах, а також при безсонні, лихоманці, простудних захворюваннях, епілепсії. Зовнішньо відвар ефективний у вигляді примочок при екземі. Іноді його застосовують при ерозії шийки матки у вигляді спринцювань і внутрішньо, а також при маткових кровотечах і тривалих місячних [4, 28-30].
У тибетській медицині у вигляді настоїв та відварів герань сибірську використовували для лікування запалення легень, при кон'юнктивітах. В індійській медицині екстемпоральні засоби вказаної рослини застосовують як ранозагоювальний, в'яжучий і сечогінний засіб. В Японії і на Сахаліні відвар трави приймають при вовчаку, бері-бері, застуді, хворобах серця, запаленні яєчок, а сік - для обмивання ран і пухлин [31]. У Перу відвари з підземної частини герані також використовують в онкології [32], а в Кореї і Болгарії - для лікування діареї, кишкового запалення, виражених хвороб шкіри, інфрекційних та онкологічних захворювань [33, 34]. Сировина $є$ перспективною для лікування злоякісних пухлин, шлунково-кишкових і гінекологічних захворювань [35].

Основні діючі речовини герані - геранін, корилагін та галова кислота проявили противірусні, гепатопротекторні та гіпотензивні властивості, а також вони інгібують ксантиноксидазу [30, 36-38]. Глікопротеїн, виділений з герані сибірської проявив антиоксидантну і проліферативну активність [39].

Після проведення мікробіологічних досліджень водного та водно-спиртового витягів з трави герані сибірської було встановлено помірну антимікробну та виражену фрунгістатичну дію ліофрілізованих екстрактів [40]. А гераніол, який в значній кількості міститься в траві герані сибірської, показав високу протигрибкову активність проти Candida albicans [41].

В'яжуча дія водного екстракту була вивчена експериментально в дослідах на кроликах, у яких штучно викликали пронос. При цьому спостерігалася виражена протипроносна дія. У дослідах in vitro даний екстракт в концентраціях 1:2000, 1:5000 проявляє бактеріостатичну дію щодо кишкової палички і до бактерії дизентерії [11].

Також встановлено, що екстракт трави герані сибірської справляє стимулюючий вплив на гуморальну ланку імунітету, тобто підвищує вироблення антитіл піддослідних тварин, а у дозі 1/10 від LD50 викликає помірний антигіпертензивний ефект, що супроводжувався тахікардією [42].

Дослідження анальгетичної та протизапальної дії екстракту трави герані сибірської показав його високу антиноцицептивну активність на моделі «оцтовокислих корчів» та низьку протизапальну активність на моделі карагенінового запалення [43, 44].

В інших дослідженнях спиртовий екстракт герані сибірської зменшує експресію гена інтерлейкіну-1 і циклооксигенази-2. У цьому випадку його можна використовувати як потужний протизапальний засіб при запальних алергічних захворювань [45].

Високий вміст амінокислот дозволяє розглядати траву даної рослини як потенційне джерело створення біологічно активних добавок. Вони можуть бути корисними хворим на гіпертонічну хворобу серця для запобігання інфраркту або інсульту, для нормалізації обміну речовин, прискорення одужання після операцій, зниження рівня

ISSN 2312-0967. Pharmaceutical review. 2016. № 4 


\section{Reviews}

холестерину крові і запобігання розвитку атеросклерозу, а також як імуностимулюючий засіб [22].

Зважаючи на вищесказане, можна зробити висновок, що герань сибірська - це рослина з великим ареалом поширення, достатньою сировинною базою, багатим хімічним складом та широким спектром фрармакологічної дії. Рослина здавна викорис-

\section{Список літератури}

1. Доброчаева Д. Н. Определитель высших растений Украины / Д. Н. Доброчаева, М.И.Котов, Ю. Н. Прокудин [и др.]. - [2 изд.]. - К. : Фитосоциоцентр, 1999. - 546 с.

2. Кролова Н. В. Флора УРСР / Н. В. Кролова, О. Д. Вісюліна. - К., 1962. - Т. 7. - С. 5-32.

3. Махов А. А. Зеленая аптека: Лекарственные растения Красноярского края / А. А. Махов. - [3-е изд. испр. и доп.]. - Красноярск : Кн. изд-во, 1986. - 352 с.

4. Флора Сибири: в 14 т. Т. 10 Geraniaceae - Cornaceae / М. Г. Пименов, Н. В. Власова, В. В. Зуев и др. - Новосибирск. -1996. - 254 с.

5. Соколов П. Д. Растительные ресурсы СССР: Цветковые растения, их химический состав, использование; Семейства Rutaceae - Eleagnaceae / П. Д. Соколов. - Л. : Наука, 1988. - 357 с.

6. Лікарські рослини: Енциклопедичний довідник / Відп. ред. А. М. Гродзінський. - К. : Голов. ред. УРЕ, 1989. $-544 \mathrm{C}$

7. Панченко С. М. Флора національного парку «Деснянсько-Старогутський» та проблеми охорони фріторізноманіття Новгород-Сіверського Полісся / С. М. Панченко. - Суми : Університетська книга, 2005. - 170 с.

8. Позднякова Т. А. Разработка показателей качества травы герани сибирской (Geranium sibiricum I.) / Т. А. Позднякова, Р. А. Бубенчиков // Ученые записки Орловского государственного университета. - 2014. - № 6 (62). - С. 139-140.

9. Ильина Л. П. Сравнительное содержание дубильных веществ в видах герани Бурятии / Л. П. Ильина, А. А. Воинков; науч. ред. Б. Б. Танганов // Теоретические и практические вопросы интеграции химической науки, технологии и образования: материалы Всероссийской научно-практической конференции с международным участием, 20 апреля 2016 г. - Улан-Удэ, 2016. - С. 8083.

10. Разаренова К. Н. Сравнительная оценка содержания дубильных веществ в некоторых видах рода Geranium L. фрлоры Северо-Запада / К. Н. Разаренова, Е. В. Жохова // Химия растительного сырья. - 2011. № 4. - С. 187-192.

11. Тхэсоп Ч. Лекарственные растения / Ч. Тхэсоп. М. : Медицина, 1987. - С. 351-352.

12. Рибак Л. М. Порівняльне дослідження кількісного вмісту елагової та галової кислот у сировині деяких видів роду герань (Geranium L.) методом високоефективної рідинної хроматографії / Л. М. Рибак // Фармацевтичний журнал. - 2011. - № 6. - С. 41-46.

13. Рибак Л. М. Дослідження нагромадження поліфенолів у кореневищах деяких видів роду Geranium L. / товується в народній медицині і $€$ перспективною сировиною для фрітохімічного і фрармакологічного дослідження з метою створення нових лікарських засобів з протимікробною, противірусною, фрунгіцидною, протизапальною, імуностимулюючою, антиоксидантною, гепатопротекторною, гіпотензивною, в'яжучою або протипроносною дією.

Л. М. Рибак // Фармакологія та лікарська токсикологія. - 2011. - № 5 (24). - С. 269-270.

14. Рибак Л. М. Порівняльне дослідження кількісного вмісту полісренолів у різних видах герані Geranium L. методом перманганатометричного титрування та спектрофотометричним методом / Л. М. Рибак, О. Ю. Коновалова, О. П. Колядич // Фармацевтичний журнал. 2010. - № 6. - С. 44-47.

15. Рибак Л. М. Дослідження поліфенольних комплексів деяких видів герані фрлори України методом BЕРХ / Л. М. Рибак // «Фармація України. Погляд у майбутнє»: VII Національний з'їзд фрармацевтів України, 15-17 вересня 2010 р. : тези доп. - Х. : Видавництво НФаУ, 2010. - C. 331-332.

16. Бубенчиков Р. А. Изучение состава фенольных соединений герани сибирской методом ВЭЖХ / Р. А. Бубенчиков, Т. А. Позднякова // Медико-социальная экология личности: состояние и перспективы : материалы XII междунар. конф., 11-12 апр. 2014 г. - Минск, 2014. C. $13-15$.

17. Yao $X$. Studies on the antibacterial constituents of Geranium sibiricum L / X. Yao // Jan. - 1987. - № 22 (1). - Р. 28-32.

18. Рибак Л. М. Дослідження кількісного вмісту полісахаридних фрракцій трави різних видів роду Geranium L. / Л. М. Рибак, О. Ю. Коновалова, Т. В. Ковальчук // Актуальні питання медичної і фрармацевтичної науки та практики. - 2011. - Вип. 24, № 2. - С. 110-112.

19. Позднякова Т. А. Количественное определение фрункциональных групп пектиновых веществ травы герани сибирской (Geranium sibiricum L.) / T. А. Позднякова, Р. А. Бубенчиков // Фундаментальные исследования. - 2014. - № 11-1. - С. 110-113.

20. Бубенчиков Р. А. Исследование полисахаридного комплекса травы герани сибирской / Р. А. Бубенчиков, Т. А. Позднякова // Научные ведомости БелгУ. - 2012. Вып. 20/1, № 22 (141). - С. 140-141.

21. Никитина В. С. Содержание френольных соединений и аминокислот в надземной части Geranium pratense и G. sibiricum (Geraniaceae) / В. С. Никитина, Г. В. Шендель // Раст. ресурсы. - 2008. - Т. 44, № 2. - С. 74-81.

22. Дослідження амінокислотного складу у деяких видів роду Geranium L. України / Л. М. Рибак, О. Ю. Коновалова, О. О. Цуркан [та ін.] // Фітотерапія. - 2010. - № 1. - C. 99-104.

23. Ісюк М. В. Дослідження амінокислотного складу герані сибірської / М. В. Ісюк, І. Л. Бензель, Л. В. Бензель // Актуальні питання фрармацевтичної і медичної науки та практики. - 2012. - № 3. - С. 4-6.

ISSN 2312-0967. Фармацевтичний часопис. 2016. № 4 
24. Позднякова Т. А. Исследование эфирного масла герани сибирской (Geranium sibiricum L.) / Т. А. Позднякова, Р. А. Бубенчиков // Фундаментальные исследования. - 2014. - № 3, Ч. 3. - С. 539-542.

25. Рибак Л. М. Дослідження сировини герані сибірської (G. sibiricum L.) хромато-мас-спектрометричним методом / Л. М. Рибак, О. Ю. Коновалова // Фітотерапія. 2013. - № 3. - С. 64-67.

26. Бубенчиков Р. А. Изучение каротиноидов травы герани сибирской (Geranium sibiricum L.) / P. А. Бубенчиков, Т. А. Позднякова, О. Д. Герасимова // Молодежная наука и современность: 78-й Всерос. науч. конор. студентов и молодых ученых с междунар. участием, посвящ. 78-летию КГМУ и 80-летию со дня рождения чл.кор. РАМН, проф. А.В. Завьялова, 17-18 апр. 2013 г. : материалы конфр. - Курск, 2013. - Ч. 2. - С. 214.

27. Rybak L. Research on quantitative content of lectins in plants of the Geranium L. Genus / L. Rybak, G. Rudik // The Pharma Innovation - Journal. - 2013. - Vol. 2, No. 6. - P. 38-41.

28. Сасронов М. М. Повний атлас лікарських рослин / М. М. Сафонов. - Тернопіль : Навчальна книга-Богдан, 2010. - $384 \mathrm{c}$.

29. Screening for antitumor efficacy from the wild plants in Korea (II) / S. R. Lee, E. S. Yoon, S. C. Shin J. [et al.] // J. Orient. Bot. Resour. - 1993. - № 6. - P. 25-32.

30. Antioxidant activities and xanthine oxidase inhibitory effects of extracts and main polyphenolic compounds obtained from Geranium sibiricum L / W. Nan, Z. Yuangang, F. Yujie [et al.] // J. Agric. Food Chem. - 2010. - № 58. P. 4737-4743.

31. Шретер А. И. Лекарственная фрлора Дальнего Востока / А. И. Шретер. - М. : Медицина, 1975. - С. 167-168. 32. A survey of traditional medicinal plants from the Callejon de Huaylas, Department of Ancash, Peru. / G. B. Hammond, I. D. Fernandez, L. F. Villegas [et al.] // J. Ethnopharmacol. - 1998. - № 61. - P. 17-30.

33. НикитинаВ. Ф.РастенияЮжногоУрала-продуценты фенольных соединений с антиоксидантными свойствами / В. Ф. Никитина, А. Я. Герченов, Г. Г. Гарифуллина [и др.] // 2-я Всероссийская конореренция «Химия и биотехнология растительных веществ», 24-27 июня 2002 г. : тез. докл. - Казань, 2002. - С. 106-116.

34. Никитина В. Ф. Содержание гидроксикоричных кислот и фрлавоноидов в экстрактах полиоренольных растений Южного Урала / В. Ф. Никитина // Прикладная биохимия и микробиология. - 2007. - Т. 43, № 6. - С. 705-712.
35. Zhexiong J. Effects of geraniin in Geranium sibiricum L. on antioxidant function of $\mathrm{S}_{180}$ mice / J. Zhexiong, S. Renshuang // Human health and biomedical engineering: international conference, 19-22 Aug. 2011. - Jilin, China, 2011. - P. 896-899.

36. Cheng J. T. Antihypertensive effect of corilagin in the rat / J. T. Cheng, T. C. Lin, F. L. Hsu // Can. J. Physiol. Pharmacol. - 1995. - № 73. - P. 1425-1429.

37. Antioxidant and hepatoprotective actions of medicinal herb, Terminalia catappa L. from Okinawa Island and its tannin corilagin / S. Kinoshita, Y. Inoue, S. Nakama [et al.] // Phytomedicine. - 2007. - № 14. - P. 755-762.

38. Antiviral effect of octyl gallate against DNA and RNA viruses / M. Uozaki, H. Yamasaki, Y. Katsuyama [et al.] // Antiviral Res. - 2007. - № 73. - P. 85-91.

39. Shim J. U. Anti-oxidative and anti-proliferative character of glycoprotein isolated from Geranium sibiricum Linne in Chang liver cells / J. U. Shim, K. T. Lim // Environ. Toxicol. Pharmacol. - 2008. - № 26. - P. 320-324

40. Одержання фрітосубстанцій із герані сибірської та вивчення їх антимікробних властивостей / М. В. Ісюк, І. Л. Бензель, О. Л. Левчук [та ін.] // Український медичний альманах. - 2012. - Том 15, № 5 (додаток). - С. 116-119. 41. Investigating the antifungal activity and mechanism(s) of geraniol against Candida albicans strains / M. C. Leite, A. P. de Brito Bezerra, J. P. de Sousa [et al.] // Medical Mycology. - 2015. - Vol. 53, No. 3. - P. 275-284.

42. Меньшова В.O. Рід Geranium L. - перспективні рослини для медицини / В. О. Меньшова, Л. М. Рибак, О. Ю. Коновалова // Вісник Київського національного університету імені Тараса Шевченка. Інтродукція та збереження рослинного різноманіття в природі та культурі. - 2012. - № 30. - С. 29-32.

43. Рибак Л. М. Дослідження аналгетичної та протизапальної активності трави різних видів роду Geranium L. / Л. М. Рибак // Науково-технічний прогрес і оптимізація технологічних процесів створення лікарських препаратів: 4-а наук.-практ. конфр. 3 міжнар. уч., 29-30 вересня 2011 р. : тез. доп. - Тернопіль, 2011. - С. 223-224.

44. Рибак Л. М. Дослідження гострої токсичності, протизапальної та аналгетичної активності екстрактів трави різних видів роду Geranium L. / Л. М. Рибак // Фармакологія та лікарська токсикологія. - 2011. - № 6. - С. 6165 .

45. Shim J. U. Anti-inflammatory activity of ethanol extract from Geranium sibiricum Linne / J. U. Shim, P. S. Oh, K. T. Lim // J. Ethnopharmacol. - 2009. - № 126. - P. 90-95.

\title{
ОБЗОР НАУЧНЫХ ИССЛЕДОВАНИЙ С ЦЕЛЬЮ ПОЛУЧЕНИЯ НОВЫХ ФИТОПРЕПАРАТОВ НА ОСНОВЕ ГЕРАНИ СИБИРСКОЙ
}

\author{
О. И. Гордиенко ${ }^{1}$, И. Л. Бензель ${ }^{2}$, Т. А. Грошовый ${ }^{1}$ \\ ГВУз «Тернопольский государственный медицинский университет имени И. Я. Горбачевского Мз \\ Украины» ${ }^{1}$ \\ Львовский национальный медицинский университет имени Данила Галицкого²
}

Резюме: в обзоре литературы обобщены данные о ботанической характеристике, распространении, химическому составу и применении герани сибирской.

ISSN 2312-0967. Pharmaceutical review. 2016. № 4 
Ключевые слова: герань сибирская, Geranium sibiricum L., ботаническая характеристика, химический состав, применение.

\section{REVIEW OF RESEARCHES WITH THE AIM TO OBTAIN NEW HERBAL MEDICINAL PRODUCTS ON THE BASIS OF SIBERIAN CRANESBILL}

\section{O. I. Hordiienko' ${ }^{1}$, I. L. Benzel' ${ }^{2}$, T. A. Hroshovyi ${ }^{1}$}

I. Horbachevsky Ternopil State Medical University ${ }^{1}$ Danylo Halytskyi Lviv National Medical University ${ }^{2}$

Summary: this review summarizes literature data of botanical characteristics, distribution, and use of the chemical composition of the Siberian cranesbill.

Key words: Siberian cranesbill, Geranium sibiricum L., botanical characterization, chemical composition, application.

Отримано 18.10.2016 